$7^{\circ}$ Simposio Internacional de Investigación Multidisciplinaria / Ciencia y Tecnología 7th Internationalm Symposium on Multidisciplinary Research / Sciences and Technology

\title{
CT-11 Ventajas de los jardines verticales sobre edificios de concreto en clima cálido-seco de Guatemala
}

Advantages of vertical gardens over concrete buildings in warm-dry climate of Guatemala

\author{
Claudia Taracena*
}

Escuelas de Estudio de Postgrado, Facultad de Ingeniería y Centro Universitario de El Progreso

Universidad de San Carlos de Guatemala (Usac), Guatemala

*Autor al que se dirige la correspondencia: claudia.taracena@cunprogreso.edu.gt

\section{Resumen}

Q 1 Centro Universitario de El Progreso de la Usac se encuentra en Guastatoya en el denominado corredor seco Cde Guatemala, ya que posee una temperatura anual de $27-34^{\circ} \mathrm{C}$, en un clima cálido-seco. Por la incidencia solar que reciben las aulas durante todo el año, se decidió utilizar un jardín vertical como sistema de enfriamiento pasivo, que se hizo con estructura de pino tratado, neumáticos de caucho reutilizados como macetas y vegetación local. Se tomaron datos de temperatura y humedad relativa ambiente, la temperatura y humedad relativa del salón cubierto por el jardín vertical y un salón sin cubierta adicional al muro de concreto, durante 30 días dispersos de enero a abril, para cubrir la época más fría y más caliente del año. La máximo disminución de temperatura fue $2.3^{\circ} \mathrm{C}$ y un incremento de humedad relativa de $4.4 \%$. El confort higrotérmico se midió por una encuesta entre estudiantes de agronomía con jornada de 7:00 a 16:00 h, dando como resultado que solamente el 8.4\% de los estudiantes encuestados percibieron mayor confort higrotérmico, esto se cree que fue porque el jardín vertical se encontraba en su etapa inicial y con poca proliferación vegetal para producir el efecto deseado. Se recomienda repetir el estudio durante el 2018, cuando el jardín vertical esté más maduro.

Palabras claves: Enfriamiento pasivo, humedad relativa, confort higrotérmico

\begin{abstract}
$\mathrm{T}$ The University center of El Progreso, is located in Guastatoya in the dry corridor area of Guatemala; since it has an annual temperature of $27-34^{\circ} \mathrm{C}$, in a warm-dry climate. Due to the solar effects received throughout the year by the classrooms, it was decided to use a vertical garden as a passive cooling system, which was made with treated pine structure, reused rubber tires as pots and local vegetation. Environmental temperature and relative humidity data were taken, as well as the temperature and relative humidity of the classroom covered by the vertical garden and a classroom without additional covering, during 30 dispersed days from January to April, to cover the coldest and hottest time of the year. Maximum temperature decrease $2.3^{\circ} \mathrm{C}$ and relative humidity increase $4.4 \%$. Hygrothermic comfort was measured by surveys among agronomy students from 7:00 to 16:00 h, showing that only $8.4 \%$ of the students surveyed perceived greater hygrometric comfort; it is believed that was because the vertical garden was in its initial stage and with little plant proliferation to produce the desired effect. It is recommended to repeat the study during 2018 , when the vertical garden is more mature.
\end{abstract}

Keywords: Passive cooling, relative humidity, hygrothermic comfort 